ELORE (ISSN 1456-3010), vol. $12-1 / 2005$.

Julkaisija: Suomen Kansantietouden Tutkijain Seura ry.

Toimittaneet: Outi Fingerroos ja Kaarina Koski. Taitto: Jukka Talve.

[http://cc.joensuu.fi/ loristi/1_05/kos1_05.pdf]

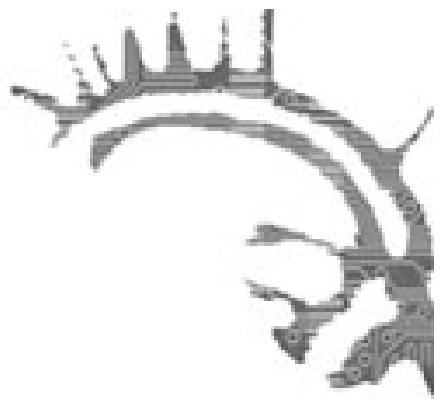

\title{
SUHDE VAINAJAAN INKERILÄISISSÄ KUOLINITKUISSA
}

\author{
Kaarina Koski
}

Inkeriläisissä itkuissa vainajille esitetään kysymyksiä, kehotuksia ja moitteita, joiden konkreettisuus hämmästyttää. Vainajaa esimerkiksi kehotellaan nousemaan haudasta ylös tai ruokkimaan ja vaatettamaan lapsiaan:

Miks et havaitse miun ämmäni hautomainen,
etkä nouse kuopasta miun ämmäni kuorimainen?

(1844:11-12)

I noiseha heitä laattimaa siä laukkoilintuisijas

i noiseha hot saamaa leippää leeminaoksaisilles

inoiseha hot saamaa vaatetta vaapuk.kalintuisille miun vanhempaan vaapuk.kakuk.ka

i noiseha hot kasvattelomaa heitä vanhempaan kailoikuke.k.

(1606:30-33)

Vainajaa pyydetään myös palaamaan, vaikka toisaalta paluu pyritään rituaalisesti nimenomaan estämään. Tässä artikkelissa tarkastelen inkeriläisiä kuolinitkuja ja eritoten vainajalle esitettyjä kehotuksia suruprosessin näkökulmasta. Esittelen itkuissa toistuvia eron kyseenalaistamisen tapoja sekä lintumotiivia, jolla usein viitataan vainajan paluuseen. Näkökulmanani on kyseisten teemojen psyykkinen tarkoituksenmukaisuus: ne ilmaisevat tunteita, joiden läpikäyminen edistää suruprosessia ja sitä kautta elämän jatkumista menetyksen jälkeen. Suruprosessin tavoitteet paljastuvat kuitenkin kulttuurisidonnaisiksi: toisin kuin psykoanalyysiin nojaava tutkimus edellyttää, inkeriläislesket eivät ole pyrkineet irrottautumaan vainajan muistosta täydellisesti vaan vaalineet henkistä sidettä itkuin. Nostankin tässä kirjoituksessani itkujen kulttuuriset merkitykset psyykkisen tason rinnalle. Hautausriitin tarkastelu kulttuurisesti ideaalisen siirtymän mallina auttaa myös ymmärtämään itkujen ilmentämän, myönteisen vainajakuvan jyrkkää eroa tarinoissa ja uskomuksissa esiintyviin pelättyihin vainajiin.

Inkeriläisiä itkuja on tutkinut kattavimmin ja seikkaperäisimmin Aili Nenola, jonka toimittamassa Inkerin itkuvirret - Ingrian Laments -teoksessa (2002) 


\section{KaARINA KOSKI}

on myös julkaistu kommentein varustettuina ja englanniksi käännettyinä kaikki Inkeristä tallennetut itkut. Aineistoviittausten numerointi tässä kirjoituksessa noudattaa julkaisun numerointia. (1) Vaikka inkeriläisten itkujen kieltä voi periaatteessa ymmärtää suomen kielen pohjalta, Nenolan käännökset edesauttavat huomattavasti inkeriläisten itkuaineistojen käytettävyyttä ja ymmärrettävyyttä. Tärkeä merkitys on myös hänen laatimallaan itkukielen erikoissanastolla (Nenola 2002, 809-828) sekä analyysillaan itkuille ominaisista henkilönnimityksistä (Nenola-Kallio 1982, 33-43). Nenola on tutkinut myös muun muassa itkujen alueellisia eroavaisuuksia Inkerissä sekä naisten roolia kuolemanrituaaleissa (Nenola-Kallio 1973;1982; Nenola 1986, 127-165; 2002). Inkeriläisiä ja yleisemmin itämerensuomalaisia itkuvirsiä on käsitellyt myös Lauri Honko (esim. 1963; 1974; 1978). Lisäksi inkeriläisten itkuvirsien analyysi saa tukea ja näkökulmia karjalaisitkuihin painottuvasta tutkimuksesta (esim. Konkka 1985; Utriainen 1998).

Inkeri levittäytyy Nevajoen suulta pohjoiseen ja länteen pitkin Suomenlahden rantaa. Alueella on asunut useita etnisiä ryhmiä, sekä luterilaisia että ortodokseja. Inkeriläiset elivät 1800-luvun puoliväliin saakka maaorjuudessa: hoitivat palkatta aatelisten pellot ja rakennukset ja olivat näiden käskyvallan alaisia henkilökohtaisissakin asioissaan. Perinteenkerääjien matkakertomukset kuvaavat väestöä huonokuntoiseksi ja nälän heikentämäksi. Seutu pysyi köyhänä ja takapajuisena pitkään maaorjuuden lakkauttamisen jälkeenkin. (Nenola 2002, 13-18.) Vaikeiden olojen on katsottu heijastuvan Inkerissä etenkin naisten esittämään perinteeseen. Agraarikulttuurissa köyhyyden, sairauksien ja sodan onkin arveltu iskeneen vahvimman leimansa juuri naisten elämään. (Apo 1989, 161.)

Itkuvirret ovat Inkerissä, kuten yleensä muuallakin, olleet naisten ylläpitämää perinnettä. Inkeriläisnaisen asemaa määritteli voimakkaasti se, oliko hänellä miestä, vanhempia tai aikuista poikaa. Leskeys saattoi syöstä naisen lapsineen taloudelliseen perikatoon - samoin työikäisen pojan kuolema. (Nenola-Kallio 1982, 103-106; Apo 1989, 162.) Inkeriläiset itkut ja laulut antavat kuvan myös äidin ja tyttären välisen suhteen erityisyydestä ja tärkeydestä. Oma äiti oli tyttärelle naisen roolin ja työtehtävien neuvoja ja opettaja ja samalla tärkein henkinen tuki. (Apo 1989, 165.) Eniten itkuja on esitetty juuri näille henkilöille, joista itkijä on ollut eniten riippuvainen: lesket aviomiehilleen tai työiässä kuolleille pojilleen, tyttäret äideilleen. Vaikka kaikkiin hautauksiin on kuulunut rituaalinen itkeminen, näille tärkeille ihmisille on esitetty itkuja, jotka ylittävät selkeästi rituaalisen välttämättömyyden.

Vaikka käytän apunani myös kontekstitietoja Inkeristä ja itkemisestä, varsinaisena tutkimuskohteena ovat itse tekstit. Tekstipohjaista tutkimusta on toisinaan pidetty riittämättömänä lähestymistapana itkuvirsiin (esim. Honko 1963, 94). Tunteisiin, yhteisöllisyyteen, naiseuteen ja ruumiilliseen kokemiseen liittyviä vivahteita ei ole helppo tavoittaa kontekstuaalisen informaationkaan avulla (Utriainen 1999, 44-45). Perinnetieteellisessä emootiotutkimuksessa kohteena eivät kui-

tenkaan voi olla yksilön sisäiset tuntemukset vaan niiden kollektiiviset olomuodot 
(Timonen 2004, 309). Tässä käsittelemäni teemat ovat kuolinitkuissa toistuvia ja stereotyyppisiä (ks. esim. Nenola 2002, 738-739). Tarkastelen niitä kulttuurisena surun ja menetyksen prosessoinnin väylänä.

\section{RituaAlien fUnKTiot JA PELKo}

Rituaaliseen perinteeseen liittyy useita sekä tiedostettuja että tiedostamattomia piirteitä, jotka tekevät rituaalien suorittamisesta mielekästä ja merkityksellistä toimintaa. Nämä tekijät voivat olla kulttuurisia, sosiaalisia tai psyykkisiä. Sosiaalisesta näkökulmasta kuolinriittien ideana on pidetty vainajan sosiaalisen persoonallisuuden vähittäistä hajoamista sekä yhteisön tasapainon ja yhtenäisyyden säilymistä kriisitilanteessa (Nenola 1985, 180). Tässä kirjoituksessa rajaan lähemmän tarkastelun kulttuurisiin ja psyykkisiin tekijöihin.

Osallistujat itse antavat rituaaleille kulttuurisia, käytännössä usein uskonnollisia selityksiä, jotka perustuvat paikalliseen uskomusjärjestelmään. Ne ovat heille itselleen välittömin, tiedostettu motivaatio riittien suorittamiseen. Tyypillinen kulttuurinen selitys kuolinriiteille on vainajan siirtäminen tuonpuoleiseen ja erityisesti toimen suorittaminen niin, että tämä siirtyy hyvillä mielin eikä kanna kaunaa (esim. Alexiou 1974, 17-22; Honko 1963, 114). Itkut, samoin kuin vainajan varustaminen ja muut rituaaliset toimet, on tällaisten uskonnollisten selitysten pohjalta tulkittu pohjimmiltaan varautumiseksi pelättyä vainajaa vastaan (esim. Haavio 1930, 99-100; Westermarck 1908, 539).

Ihmisillä on monia syitä pelätä kuoleman äärellä. Läheisen kuolema koetaan uhkaksi omallekin olemassaololle, ja sen yhteydessä tunnetaan pelkoa, vihaa ja syyllisyyttä. Pelko liittyy aina eksistentiaalisiin kysymyksiin: menetys horjuttaa vakiintunutta identiteettiä ja turvattuja tulevaisuudennäkymiä sekä muistuttaa omankin olemassaolon päättymisestä kuolemassa. Viha kohdistuu kaikkiin niihin, jotka eivät kyenneet estämään menetystä, sekä vainajaan, joka kuollessaan hylkäsi surijan. Syyllisyys taas kumpuaa kaikesta siitä, mikä olisi pitänyt tehdä toisin vainajan vielä eläessä sekä siitä, että itse jäi henkiin vaikka toinen kuoli. Syyllisyys voi herättää yksilössä tarpeen hyvittää tekonsa tai jopa tulla rangaistuksi. (Lazarus 1999, 235, 243.) Vainajaa kohtaan tunnettu syyllisyys voi johtaa vainajan pelkäämiseen ja hänen kostonsa odottamiseen.

Rituaaleja on usein tarkasteltu keinona hallita vainajia kohtaan tunnettua alkukantaista pelkoa. Pelon hallintaa rituaalien ja lohdullisten mielikuvien avulla on pidetty kulttuurin kehittymisen tuotteena. (Esim. Malinowski 1960, 50-56; Kleinpaul 1898, 159; Westermarck 1908, 534-535; Freud 1989, 78.) On kuitenkin selvää, etteivät pelot synny vain itsestään psyykkisistä syistä eivätkä kulttuurin välittämät mielikuvat ole yksinomaan lohdullisia. Useissa kulttuureissa vainajien pelko on institutionalisoitu ja uskonto siis myös lietsoo sitä. Pelko motivoi suorittamaan rituaaleja, joilla on yhteisöä lujittava vaikutus ja jotka usein myös tukevat omaisten sopeutumista uuteen tilanteeseen. Pelolle on oma tehtävänsä myös 
psyykensisäisessä suruprosessissa: omaiset ovat motivoituneempia irrottautumaan vainajan muistosta ja orientoitumaan elämään uudelta pohjalta, kun mielikuvat vainajasta ovat ahdistavia. (Rosenblatt et al. 1976, 61-63.)

Sigmund Freud tulkitsi vainajaa kohtaan tunnetun pelon projektioksi surijan omista negatiivisista tunteista, jotka tämä pyrkii tukahduttamaan. Psyykkisen surutyön tehtävänä on tällöin irrottaa surijan muistot ja odotukset kuolleesta. Vasta sen jälkeen hellittävät tuska, syyllisyydentunto ja viha sekä niistä kumpuava pelko. (Freud 1989, 80-85.) Itkuvirsien strategia on toinen: ne tarjoavat negatiivisille tunteille kulttuurisesti hyväksytyn purkautumistien. Rituaalinen konteksti varautumiseen luo turvallisen kanavan vainajaan, ja itkijä voi näin käsitellä vainajaan kohdistuvia tunteitaan.

Psykotieteiden piirissä kuolemaan liittyviä rituaaleja on suhteutettu ahdistuksen purkamiseen ja suruprosessin etenemiseen (esim. Scheff 1977, Pollock 1972). Hautausrituaaleja ei voi johtaa suoraan universaaleista psyykkisistä ominaisuuksista (Metcalf \& Huntington 1991, 61-62), mutta niiden mielekkyyttä lisää se, että ne vastaavat kriisitilanteessa nouseviin psyykkisiin tarpeisiin.

\section{KUOLINRITUAALIEN USKONNOLLISET JA KULTTUURISET MERKITYKSET}

Émile Durkheim selitti rituaaleihin osallistujien antavan toimilleen mytologisia selityksiä siksi, etteivät he tunne suremisriittien todellisena pohjana olevia psyykkisiä mekanismeja (Durkheim 1980, 350-355). Rituaalien uskonnollisia tulkintoja ei kuitenkaan pidä sivuuttaa pelkkänä pintakerroksena ja paremman tiedon puutteessa annettuina selityksinä. Juuri niiden avulla ritualisoidut tapahtumat tehdään omassa kontekstissaan mielekkäiksi ja kuolemankin olemassaolo selitetään, jopa oikeutetaan. Kuoleman legitimointi tapahtuu yleensä liittämällä se ajatukseen elämän jatkumisesta kaikesta huolimatta. (Berger \& Luckmann 1994, 111-117.)

Antropologit ovat havainneet rituaalien varsin usein yhdistävän kuoleman uudelleensyntymään tai hedelmällisyyteen. Kun elinvoima mielletään rajalliseksi resurssiksi, jokainen kuolema on etenkin syklisen aikakäsityksen puitteissa mahdollisuus uudelle elämälle, regeneraatiolle. Kuolemanrituaalien avulla yhteisö huolehtii siitä, että kuolemassa vapautunut elinvoima ohjataan takaisin yhteisön käyttöön. (Bloch \& Parry 1982, 5-11.) Rituaalit edustavat siis ideaalista siirtymää. Kun vainaja liittyy esi-isien joukkoon, resurssi palaa tuonpuoleisen kautta yhteisön käyttöön viljan, ihmisten tai riistan hedelmällisyytenä. Sellaista kuolemaa, josta ei seuraa yhteisöä hyödyttävää regeneraatiota, pidetään pahana kuolemana. Pahan kuoleman uhreja, kummituksia ja rauhattomia vainajia kuvaavat kertomukset edustavat epäilyksiä siitä, ettei kuolema rituaaleineen hoitunutkaan asianmukaisella tavalla. (Bloch \& Parry 1982, 15-18.)

Tämä johtaa vainajamielikuvien kaksijakoisuuteen. Inkerissäkin itkut ilmentävät hellää ja luottavaista suhdetta vainajiin, vaikka väestön myös tiedetään 
pelänneen kuolleita ja kummittelua (esim. Törneroos \& Tallqvist 1860, 155). Inkeristä on myös tallennettu uskomustarinoita, joissa vainajille esitetyistä leikillisistä kehotuksista seuraa näiden raivostunut hyökkäys (Jauhiainen 1999, 110). (2) Eurooppalaisissa viljelykulttuureissa regeneraation idea on yhdistetty peltojen viljavuuteen. Suomen rautakautisten kalmistojen on tulkittu viittaavan suoraan suhteeseen vainajien ja pellon hedelmällisyyden välillä. Viljelykulttuureille tyypillisen syklisen aikakäsityksen myötä yhteisön nykyiset ja edesmenneet jäsenet ovat läsnä samassa maisemassa ja samassa elämän kierrossa. (Purhonen 1998, 40-42; ks. myös Cavendish 1975, 48.) Kuoleminen vieraalla maalla merkitsee, etteivät omaiset voi suorittaa asianmukaisia rituaaleja ja kuolijan kohtalona on jäädä harhailemaan. Regeneraation näkökulmasta kummittelu edustaa energiaa, joka ei ole siirtynyt eteenpäin yhteisön kierrossa. Vaikka tällaisen kierron idea ei liene enää ollut aktuaali kristillistyneessä Inkerissä, se hahmottuu kuolemaa koskevien käsitysten taustalle. Sekä inkeriläiset että karjalaiset itkut ja runot osoittavat, että kuolemista vieraalla maalla on pidetty yksilön kannalta onnettomana kohtalona (Nenola-Kallio 1982, 103; Järvinen 2004, 201). Yhteisölle ongelmallisempia ovat syntiset ja vääryyttä kärsineet vainajat, jotka palaavat kotonakulkijoina häiritsemään omaisiaan.

Inkeriläiseen hautausriittiin kuuluneissa itkuissa vainajan saattaminen Tuonelaan näkyy tekstin tasolla selvästi. Itkijä kuvailee tuonpuoleiseen johtavaa tietä ja siellä odottavia vastaanottajia: tuomareita, jotka esittävät vainajalle kysymyksiä ja päättävät niiden mukaan tämän tulevan paikan. Itkijä koettaa myös pehmittää tuomarien mieltä vakuuttelemalla, että vainaja on jo eläessään kärsinyt tarpeeksi. (Honko 1978, 89; Nenola-Kallio 1982, 104-105.) Hautaan saattamiseen kuuluvat myös anteeksipyynnöt sekä vainajalta että hänen puolestaan, jotta selvittämättömät asiat eivät estäisi siirtymistä tuonpuoleiseen. Lauri Hongon mukaan inkeriläinen itkijä toimii psykopompoksena, välittäjänä tämän- ja tuonpuoleisen välillä. Itku on rituaalista kieltä, jonka vainajan on uskottu kuulevan tuonpuoleiseen. (Honko 1978, 89.) Omaiset saattavat kokea riitin ennen kaikkea vainajasta huolehtimiseksi, mutta laajemmalla yhteisöllisellä tasolla - edelleen uskomusten näkökulmasta - kysymys on myös yhteisöä, sen elinkeinoja ja menestystä koskevien mahdollisten uhkien eliminoinnista. Yhteisö toivoo, ettei vainaja myöhemmin palaa esittämään vaatimuksia vaan toimii tuonpuoleisessa sukunsa hyväksi. (Honko 1963, 114.)

Aili Nenola on huomauttanut, että 1800-luvulla Inkeristä tallennetuissa itkuissa tuonpuoleiseen saattamisella on jo toisarvoinen merkitys. Itkujen fokus on tämänpuoleisessa, menetyksen kokeneiden omaisten surussa ja kovassa kohtalossa. (Nenola-Kallio 1982, 104.) Samoin Unelma Konkan mukaan karjalaisten itkujen kolmesta peruskomponentista varautuminen ja vainajan tarpeista huolehtiminen ovat lähinnä kivettymiä mutta rakkauden osoittaminen ja sureminen todellisia funktioita. Itkujen emotionaalinen merkitys on vahvistunut, ja niitä on viime vaiheessa esitetty etupäässä traagisen tai omaisia muuten järkyttäneen kuoleman yhteydessä. (Konkka 1985, 30, 94.) Itkuja on tarvittu tueksi silloin, kun kuoleman hyväksyminen on ollut erityisen vaikeaa. 


\section{KAARINA KOSKI}

\section{KATHARSIS JA TUSKIEN TUULLUTTAMINEN}

Lauri Honko on korostanut itkujen emotionaalista latausta, joka valtaa itkijän lisäksi muutkin riittiin osallistuvat. Suremisriitit eivät ainoastaan säännöstele surua vaan myös pakottavat asianosaiset suremaan. Elämys on katharttinen ja luo edellytykset vainajan muiston etäännyttämiselle ja elämän normalisoitumiselle kuolemantapauksen jälkeen. (Honko 1963, 116.) Katharsis voidaan määritellä ahdistuksen purkamiseksi kokemalla ahdistavat tunteet uudelleen. Draaman tai rituaalin keinoin tunteet voidaan etäistää niin, että kokija pystyy sekä tarkkailemaan tilannetta että samalla osallistumaan siihen emotionaalisesti. Ilman tällaista kaksoisroolia katharsis ei ole mahdollinen: ellei kokemusta etäistetä, se vain lisää ahdistusta. Jos sitä taas tarkkaillaan vain ulkoapäin, sillä ei ole emotionaalista vaikutusta. (Scheff 1977, 485-487.) Thomas J. Scheff on analysoinut ahdistuksen purkamista kollektiivisesti uskonnollisten rituaalien avulla ja väittää etäistämisen perustuvan uskon ja epäuskon samanaikaiseen kokemiseen rituaalissa. Osallistujat näin ollen sekä uskovat olevansa yhteydessä tuonpuoleiseen että vain näyttelevät. (Scheff 1977, 488-489.)

Itkut käyttävät toisinaan vahvoja mielikuvia ja drastisia ilmauksia saadakseen surijan itkemään ja sitä kautta purkamaan ahdistustaan (Nenola 1991, 17). Kreikkalaisissa itkusäkeissä kyyneliä kuvataan suloisiksi (sweet); katharttinen itku on helpottava kokemus (Alexiou 1974, 125; Scheff 1977, 489). Myös laululyriikalla, ns. huolilauluilla, on katsottu olevan terapeuttinen merkitys (Apo 1989, 177). Väinö Salminen on kuvaillut itkujen ja huolilaulujen esittämistä arjen keskellä: kun suru purkautuu itkun tai laulun muodossa ulos, laulaja rauhoittuu ja tyyntyy pian jatkamaan arkisia töitään (Salminen 1945, 594).

Inkeriläisistä itkuteksteistäkin voi päätellä, että äänellä itkeminen on koettu helpottavaksi surujen äärellä. Seremoniallisen kontekstin ulkopuolella esitetyissä tilapääitkuissa itkijä saattaa ilmoittaa tavoitteekseen tuskien tuulluttamisen (esim. 4360:9, 4534:24, 4608:2, 4610:1-4, 4643:2). Tuskien tuulluttamisella ja sen kertosäkeenä käytettävällä halujen harottamisella tarkoitetaan myös lyyrisissä huolilauluissa surun hajottamista ja levittämistä; suru päästetään pois minän sisuksista ja hajotetaan maailmaan. Erityisesti itkuissa korostuu, että tuskien tuulluttamiseen tarvitaan myös kuulijaa; se ei onnistu yksin. (Timonen 2004, 351-353.)

Itkutilanteiden kuvaukset viittaavat usein kokemuksen kollektiivisuuteen (Utriainen 1998,189-192), mutta kuulijan kaipuu näkyy myös tekstin tasolla. Akulina Kirillovalta vuonna 1971 tallennettu Itkuvirsi naapurin elämästä (4642) viittaa tilanteeseen, jossa vanhat ystävykset helpottavat oloaan itkemällä toisilleen. Riveillä 1-5 Kirillova kehottaa naapuriaan kertomaan murheistaan, jotka itkijäkin tietää ja tuntee, sekä riveillä 16-19 vastavuoroisesti lievittämään itkijän tuskia, jotka niin ikään ovat molemmille tuttuja. Kirillovalta vuonna 1968 tallennettu Itkewvirsi ystävätärvainajalle (1623) viittaa samaan. Ystävättären kuoltua itkijä valittaa: 
SUHDE VAINAJAAN INKERILÄISISSÄ KUOLINITKUISSA

\section{A kellepä nyt siis noisen kaihoelomaa kaiholoi, a kelle noisen nyt tuulottelomaa tuskijaan?}

(1623:13-14.)

Henkilökohtaisten murheiden valittamista kyläläisten kuullen ei pidetty sopivana (Virtanen 1985, 127). Surut jakavaa läheistä ystävää - usein äitiä - kaivattiin kuolemankin yli. 35-vuotias Varpu Laukaan Kosemkinasta itki äitinsä haudalla:

Nyt lienen eksynyt nïnkuin Jumalan lintu puun oksalle.

Ei ole ketään kenenkä päin yhessä haastella omia balusanoja

ja kurtella syämeltä omia murheellisia murheita,

vaikea tuskaan tukehtuisin tusakasaikainen

vaike a nälkäänkin nääntyisin mie onnetoin oksa.

Ko tuloo syämellinen murbe miulle muurekasaikaiselle,

kun tulen tuwittajani

bauallesi bautojani

kääpällesi kääriäni

kuopallesi kuorijani

havaitse hauasta hautojani

ja vastaele miulle vaipuneelle

hot buokauksilla miulle suuribuolekkaalle,

jot kerkenisivät miun syämelliset murheet

ett' viikon jälleen jaksaisin virheisemmästi viettää.

(1858:11-25.)

\section{RITUAALIT SURUPROSESSIN EDISTÄJINÄ}

Psykotieteissä suremista tarkastellaan sopeutumisena uuteen tilanteeseen, jossa vainaja ei enää vastaa surijan tarpeisiin. Suruprosessin - samoin kuin rituaalisen suremisen - päämääränä on rakentaa tätä uutta tilannetta vastaava sisäinen ja ulkoinen tasapaino. Suruprosessi koostuu tietyistä reaktioista aikajärjestyksessä ja tietyssä suhteessa prosessin akuuttiin ja krooniseen vaiheeseen, päätyen vähitellen psyykkiseen tasapainoon. Psyykensisäisen suruprosessin akuuttiin vaiheeseen liittyy aluksi shokki, menetyksen kieltäminen sekä turhautumisen ja paineiden synnyttämiä vihantunteita, jotka voivat ilmetä itsesyytöksinä. Akuutille vaiheelle ovat tyypillisiä myös sisäinen dialogi vainajan kanssa, hänen tapaamisensa unissa sekä identifioituminen kuolleeseen. Eron tunnustamisen ja irroittautumisen myötä siirrytään suremisprosessin krooniseen vaiheeseen, jossa suru ei enää ole intensiivistä ja jatkuvaa ja jossa alkaa menetyskokemuksen integrointi todellisuuteen. (Pollock 1972, 13-14, 23-24; 1974, 72-77.)

George Pollock on tutkinut suruprosessin vaiheita ja soveltanut psykoanalyyttista tietoa suremisriitteihin pääkohteenaan ortodoksijuutalaiset sururituaalit. 


\section{KAARINA KOSKI}

Hänen havaintonsa mukaan juutalaiset suremissäännöt noudattavat kronologisessa jaksotuksessaan psyykkisen suruprosessin etenemistä akuutista vaiheesta kohti kroonista. Prosessin loppuunsaattamisen jälkeen säännölliset muistopäivät auttavat käsittelemään surun jäänteitä ja tapahtuneen eron muistoa. (Pollock 1972, 13-15, 30.) Pollock tulkitsee suruprosessia edistäviksi myös monet eri kulttuurien kuolemanrituaaleissa toistuvat piirteet (Pollock 1972, 23-24). Rituaaleihin toisinaan kuuluva aggressiivinen käytös (esim. Metcalf \& Huntington 1991, 48-49) purkaa turhautumista ja vihaa. Surijaan itseensä kohdistuva väkivalta ja repiminen symboloi hänen identiteettinsä ja elämänjärjestyksensä hajoamista. Tosin se, samoin kuin surijan eristäminen ja muut tiukat säännöt, myös lääkitsevät syyllisyyttä: omaisen osa ei näin tunnu räikeästi paremmalta kuin vainajan. Kulttuurinen selitys tälle on, että leski suojautuu vainajan kateudelta rankaisemalla itse itseään (Metcalf \& Huntington 1991, 43).

Mainittuja piirteitä tavataan eri muodoissa, mutta ei suinkaan kaikista kulttuureista. Kuoleman yhteydessä koetut tunteet ovat kulttuurisidonnaisia, ja niihin vaikuttavat selvästi myös konkreettiset olosuhteet. Esimerkiksi Inkeristä saatujen tietojen perusteella lesken elinolot ovat olleet sellaiset, ettei liene järkevää puhua eloonjäämisestä johtuvasta syyllisyydentunteesta. Itkun mukaan vainajan olot ovat paremmat: hän jättää maallisen taakkansa muille ja makailee buolettomia buomenoisiaan, kun omainen sen sijaan yhä uuvuttaa itsensä kovassa arjessa (1101:9-18; 1118:53; 1121:2-5). Toisin kuin Pollockin tutkimissa juutalaisrituaaleissa, inkeriläisissä itkuissa suruprosessin kronologia ei ole olennainen. Vainajan, erityisesti aviomiehen poismenoa ja hänen jättämäänsä tyhjää paikkaa, itketään vielä vuosia jälkeenpäin, ja samat menetyksen lopullisuutta prosessoivat teemat toistuvat haudalla esitetyissä itkuissa riippumatta ajallisesta etäisyydestä hautaukseen. Inkeriläisten itkijöiden tapauksessa suruprosessi ei näyttäisi päättyvän lopullisesti Pollockin esittämällä tavalla vaan kanava menetettyyn omaiseen pidetään tietyllä tasolla auki.

Länsimaisen psykoanalyysin näkökulmasta onnistunut suruprosessi irrottaa surijoiden muistot ja toiveet vainajasta kokonaan (Pollock 1972, 12). Tällaiseen tavoitteeseen ei suinkaan pyritä kaikissa kulttuureissa. Inkerissä leskeys leimasi naisen elämää sosiaalisessa ja taloudellisessa mielessä riippumatta siitä, millainen hänen psyykkinen siteensä miesvainajaan oli. Itkuissa käsiteltiin menetyksiä, jotka määrittivät pysyvästi itkijän asemaa ja elämänkohtaloa. Kuitenkin myös henkilökohtaista suhdetta tärkeisiin vainajiin pidettiin aktiivisesti yllä.

Itämerensuomalaisella alueella vainajat ovat olleet osa moraalista yhteisöä. Karjalassa heidän on katsottu voivan ilmaista mielipiteitään elävien toiminnasta ja antaa lohdullista tietoa tuonpuoleisesta. Vainajan näkemistä unissa on pidetty mahdollisena ja positiivisena merkkinä vielä vuosia kuoleman jälkeen. Itkuja vastaavasti on pidetty kommunikaationa tuonpuoleiseen siirtyneen ystävän tai

omaisen kanssa. Vuoropuhelun kanavat ovat kuitenkin yksisuuntaisia. Elävät luovat kontaktin vainajiin muistajaisrituaalien kautta, vainajat taas eläviin unien kautta. (Järvinen 2004; Nenola 2002, 738; Stark et al. 1996, 260.) Inkeriläiset itkuvirret 
nousevat siis uskomustaustasta, johon kuuluu suruprosessin päättämisenkin jälkeen käsitys tuonpuoleisesta ja mahdollisuus kommunikaatioon edesmenneen omaisen kanssa.

\section{AlueEllisia EROJa INKERISSÄ}

Itkuaineiston analyysissa tuon esille joitakin alueellisia eroja kuoleman ja sen herättämien tunteiden käsittelyssä. Aili Nenola on jakanut Inkerin itkut kielellisten ja tyylillisten piirteiden perusteella kuuteen selvästi erottuvaan itkualueeseen: 1) Pohjois-Inkeri, 2) Äyrämöiset, 3) Hevaa, 4) Soikkola, 5) Vatjalaiset ja 6) Laukaa. Jaon taustalla vaikuttaa myös uskontoero: äänellä itkeminen ei yleensä ole kuulunut luterilaiseen kulttuuriin. Kuitenkin luterilainen äyrämöisväestö on omaksunut ilmeisesti inkeroisnaapureiltaan hääitkuja ja Laukaan alueen luterilaiset niiden lisäksi myös tavan esittää kuolinitkuja. Keski-Inkeriin sijoittuva Soikkola on inkeriläisitkujen ydinaluetta, jossa itkut ovat sisällöllisesti, kielellisesti ja käyttönsä puolesta kehittyneimpiä ja josta niitä on myös tallennettu eniten. (Nenola 1973, 93-98; 2002, 11-15, 46-49.)

Temaattiset erot eri alueiden välillä ovat selviä. Vaikka kuolinitkut kaikilla alueilla keskittyvät ennen kaikkea ongelmiin tämänpuoleisessa, Soikkolan itkuissa kuvaillaan myös Tuonelaa ja vainajan matkaa sinne. Pohjoisinkeriläisissä ja hevaalaisissa itkuissa taas ei kanneta lainkaan huolta omaisen kohtalosta tuonpuoleisessa. Hevaan itkuissa useimmin toistuva teema on vainajan paluun odottaminen, Pohjois-Inkerissä taas lesken työtaakan ja taloudellisten ongelmien käsittely. (Nenola 2002, 732-734.) Laukaalais- ja vatjalaisaineiston osalta tallenteiden heterogeenisuus ja 1900-luvulla lisääntyvä idiosynkraattisuus hankaloittaa yleisempien vertailujen tekemistä. Laukaan alueen itkut muistuttavat monin tavoin soikkolalaisia, vaikka osa pitemmistä itkuista on tallennettu luterilaisilta itkijöiltä. (Nenola 2002, 740-741, 743.) Luterilaisitkussa esiintyvä huoli tuonpuoleisesta kohtalosta on selvästi kristillissävytteinen (1832:51-56; ks. myös Nenola 2002, 744).

Tapahtuneen kuoleman kieltäminen ja eron väistämättömyyden kyseenalaistaminen ovat sellaisia itkujen teemoja, joita tarkastelen suruprosessiin liittyvinä reaktioina. Inkerin eri itkualueilla myös eron lopullisuuden retorinen käsittely tulee esille eri tavoin. Pohjoisinkeriläiset itkut eivät juuri kyseenalaista tapahtunutta eroa, vaan niissä murehditaan omaisten kohtaloa. Hevaalaisitkutkin myöntävät selkeästi tapahtuneen: sen, että vainaja on nyt salpaeltu sattoin tubantuisiin Tuonen salpaisiin (1324:23) mutta häntä kehotetaan kuitenkin käymään omaisiaan katsomassa. Vatjalaisitkuissa kyseenalaistetaan kuoleman aiheuttama fyysinen ero: tyypillinen motiivi on vainajalle esitetty pyyntö ojentaa kätensä haudasta. Itkijä myös pyytää vainajaa ottamaan hänet kainaloonsa $(1701,1706)$. Voimakkaimmin fyysisen eron kyseenalaistavat teemat tulevat esiin Soikkolan itkuissa, joissa itkijä kehottaa varsin konkreettisesti vainajaa nousemaan ylös eikä ole ymmärtävinään to- 
dellista syytä tämän reagoimattomuuteen. Analyysini perustuu etupäässä näihin Soikkolan itkuissa tavattaviin teemoihin.

\section{MaHDotToman PaLUUN TOIVEeT}

Itkemistä ei ole sopinut aloittaa ennen kuolemaa (esim. Nenola 2002, 744), vaan kuolinitkun kohde on tunnistettu ja samalla myös tunnustettu kuolleeksi, joka ei voi palata elämään entisessä, fyysisessä hahmossaan. Siitä huolimatta vainajaa pyydetään itkussa palaamaan ja kehotetaan nousemaan. Pyynnöillä ilmaistaan kiintymystä ja jälleennäkemisen toiveita; yhtäältä ne ovat omaisten aitoja tunteita, toisaalta ne taas on tulkittu myös vainajan lepyttelyksi varmuuden vuoksi (Apo 1989, 33-34). Osa pyynnöistä on luonteeltaan metaforisia. Vainajan paluuta kummituksena tai lahonneena ruumiina kammottaisiin, ja vaikkei inkeriläisissä itkuissa eksplisiittisesti kielletä tällaista ilmestymistä, niissäkin kannustetaan uskomusjärjestelmän kannalta soveliaampaan ja kauniimpaan paluuseen esimerkiksi linnun hahmossa (Törneroos \& Tallqvist 1860, 155; Honko 1963, 114-115). Paluuta lintuna voi pitää muistumana laajalle levinneistä sielulintukäsityksistä: sielu voi poistua ruumiista paitsi kuolemassa myös unen aikana (Haavio 1950, 15-19). Soveliasta on kehottaa vainajaa myös nousemaan keväällä vihreän ruohon myötä ja lentämään lehden sisässä.

Inkeriläiset itkut poikkeavat karjalaisista ja useimmista muista itkuista siinä, että niissä vainajaa todellakin myös pyydetään saapumaan omana itsenään (Honko 1978, 91). Erityisesti hevaalaisitkuissa valitetaan, eikö vainaja voisi tulla edes yhden tunnin ajaksi takaisin omaistensa luo $(1311,1313,1314)$. Koska vainaja ei muulla tavoin pääse, tulkoon lintusena (esim. 1314) tai lähettäköön edes viestin lintujen välityksellä $(1371,1696)$. Pikemmin kuin vainajan toivottuna inkarnaationa, linnut nähdäkseni toimivat inkeriläisessä itkussa rinnastuksena vainajan paluun mahdottomuuteen, kuten seuraavassa:

\section{Kaikeki ilmoin lintuset ilmahun tälle ilmaiselle kerkeäisiksi kesoipäiväsiksi, etkä siä voi ilmabuo tälle ilmaiselle kerkeäisiksi kesoikiireheisiksi.}

$$
\text { (1325:12-15.) }
$$

Lintuna lentäminen näyttäisi toimivan metaforana toiveelle kohtaamisesta, joka ei voi toteutua. Siihen kehotetaan paitsi vainajaa, myös elävää, kauas joutunutta omaista. Laukaalaisessa rekryytti-itkussa äiti kutsuu tyttärensä kuoltua kaukana sotaväessä olevaa poikaansa lohdukseen:

\section{lennä lintunna miun liekuteltuni kussa matkussat miun maksani muru juokse joutsenenna miun juomukkaiseni urossoittamaa meitä vanhoi vaipunneita}

(3916:3-6.) 


\title{
SUHDE VAINAJAAN INKERILÄISISSÄ KUOLINITKUISSA
}

Myös itkijä itse voisi siivekkäänä toteuttaa toiveensa. Leski toivoo itkussaan lentävänsä lintuna haudalle ja nostavansa miehensä haudasta (4545:86-94). Tyttärestään huolissaan oleva äiti haluaisi lentää tytärtään tukemaan:

\section{Kuin olisikin linnun siivet liioin lausebikekahal \\ kuin mie lenttäisin leeminaiselleen...}

(4595:17-18.)

Itkujen metaforiset toiveet voi tulkita ikään kuin tyytymiseksi vähempään todellisen paluun osoittautuessa mahdottomaksi. Tällainen on esimerkiksi vainajan nouseminen keväisen ruohon myötä. Kehotus liittyy itkijän toiveeseen pystyä nostamaan vainaja maasta käsin tai köysin, ja kun tämä ei onnistu, viitataan maasta nousevaan kasvullisuuteen kuten seuraavassa:

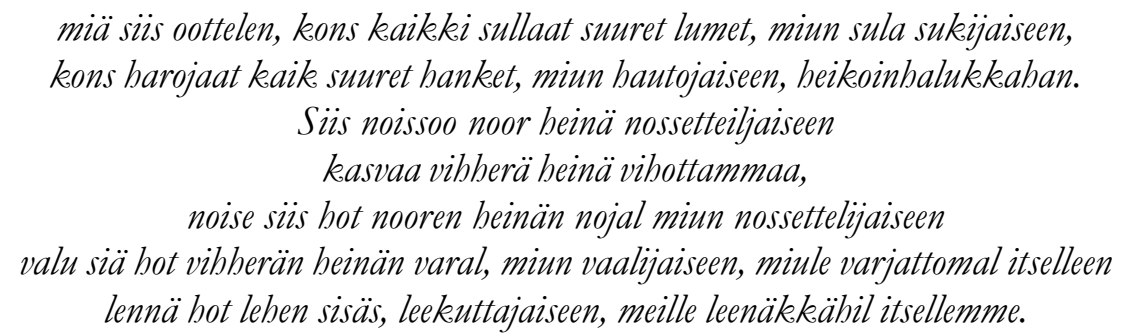

$(1605: 45-51$.

Soikkolassa on tunnettu uskomus, että vainajan kasvot voisivat ilmestyä näkyviin lattialautojen saumassa tai kurkihirren päässä (Nenola 2002, 738). Tähän mahdollisuuteen viitataan useissa soikkolalaisitkuissa. Vainajan kuvan ajatellaan lohduttavan äitiään ikävöiviä, tuuluttavan tuskia orpolapsilta tai kertovan heille, miltä isävainaja näytti. (1508: 30-35; 1614: 17-21; 1637: 43-47; 1654: 7-14; 1664: 14-15; Nenola 2002, 734.) Vainajan odotetaan näyttävän kasvonsa myös kuussa tai pilvien välissä $(1624,2329)$. Tällaisten lohdullisten kuvien mahdollisuus kuitenkin myös kyseenalaistetaan. Vainajan kuvaa etsitään, mutta sitä ei ilmesty näkyviin:

\author{
Kuin möö oomma tusal tunittajaiseen \\ ikäväl oomma imettäjäiseen, \\ isto möö kaik jo etsimmä kuvvaa kuuritsast kuvvaajaiseen, \\ ja katsomma liitsaa lauttoin liittiis laaittajaiselta, \\ mut ei vaa kussaa kunlu kuvvaa kuvvaajaiseen, \\ eikä kustaa ilmabtu äänt meijen asettajaiselta.
} (1605:52-57.)

Paikallisen uskomusjärjestelmän kannalta realistisimmalta toiveelta tuntuu vainajalle esitetty pyyntö tulla itkijän luo tämän nukkuessa puhelemaan, lohduttamaan ja neuvomaan: 


\author{
I tyehä hot univootehesse miulle voosin tooja \\ i tyehä hot makkaahostilalle läk.käämää miulle lauseenleinäkekäälle \\ tye hot siiyttelömään minnua miun syväntä syvänhalukkahaan. \\ (1622:35-37; ks. myös 1612: 67-72; 1869: 11-12).
}

Näiden edellisten lisäksi vainajaa todellakin kehotetaan saapumaan paremman puutteessa eräänlaisena haamuna ja pyydetään edes kulkemaan salaa huomaamattomissa paikoissa kuten pimeissä nurkissa, kuuritsan alla tai seinän vierillä:

Kun et voi ilmaksella ilmisilmäisin tälle ilmaiselle,
pistiellii hot pimiöin hämärä̈sin meïän pimeäisiin kolk.kaisiin,
kuunteloittele hot kuuritsan alaisilla
seisoksentele hot seinän vieryessä
(1324:11-14; vrt. 1325:9-11.)

Näistä samoista paikoista vainajaa etsitään myös hääitkussa (2309: 5-8). Soikkolassa vastaava hääitkun teema ilmaistaan toisin päin: vainajaa kielletään piileskelemästä mutta kehotetaan sen sijaan maistamaan olutta ja osallistumaan avoimesti tyttären itkuiltaan. (2435, 2487; Salminen 1916:62-63.) Sama toive esitetään myös Jumalille $(2568,2569)$.

\title{
"MiKSIPÄ ET VOI NOUSTA NOSTETELTUSEIN?"
}

Useat itkut alkavat vainajalle osoitetulla kehotuksella nousta ylös. Kotona ennen hautausta esitetyissä itkuissa vainajaa herätellään ja kutsutaan nousemaan aterialle, samoin muistajaispäivinä haudalla esitetyissä. Nousukehotukset voi tulkita vainajan hengen puhutteluksi ja kehotuksiksi tulla kuulemaan itkijää, joka on tullut häntä tervehtimään. Unelma Konkka on muistuttanut karjalaisitkujen yhteydessä, että vainajan hengen ajateltiin liikkuvan kuoleman jälkeen kuuden viikon ajan näkymättömänä vanhoilla elinsijoillaan (Konkka 1985, 75). Inkerin vatjalaisalueella näillä kehotuksilla kuitenkin on erityisen fyysinen luonne: "Avaa silmäsi, katso minuun (1731:5-6, 1732:9-10)!’ Pyynnöt ikään kuin kyseenalaistavat fyysisen eron. Vainajaa pyydetään myös ojentamaan kätensä haudasta (esim. 1700:6, 1706:4-5, 1717:8) tai ottamaan itkijä kainaloonsa (1701:8-10, 1706:10-12).

Hautauksen lopullisuus kyseenalaistetaan erityisen dramaattisesti Soikkolan itkuissa. Haudalla vierailtaessa esitetyissä itkuissa itkijä ilmaisee luulleensa, että vainaja olisi noussut haudan päälle häntä odottamaan, ja tiedustelee joskus yksityiskohtaisestikin syitä, miksei tämä ole noussut eikä edes vastaa puhutteluun. Seuraava esimerkkikatkelma on itkusta aviomiehen haudalla: 
SUHDE VAINAJAAN INKERILÄISISSÄ KUOLINITKUISSA

Hyväpäivä, vanhempien päivälle pitelömäin! Miä tulinki läkeälömmää läyleleinekäs, miä tulinki sukuttelomaa suurientusakas.

Luulinki: vai siä oot havvan partahaal paljoleinekkähälle, siä oot niin kovin kovistaant miule kovaosattomalle.

Luulinki: vai siä oot rissin varaal miule vaipunehel itselleen, miä oottelinki tätä päivääpäiväkäs aikain, tätä kuuroa kurjaleinek.kähäin.

Luulin: vai noiset kysyttelömää kyllin kyynelikekähält.

Taittaa siun ei oo volehutta vanhempien vuosien tuomain, taittaa ei oo valtaa vanhempien viljoin vaalimain, ku et nois läkkäämää miule ikiosattomalle, et voi verkeka miule vetoivirrakekahalle.

(1508:1-13.)

Vainajan paluun estymisen syyksi epäillään Tuonen herrojen tiukkuutta, joka voisi lieventyä tehokkaamman lepyttelyn avulla $(1508,1520,1576,1577)$. Vainajan kovuutta myös moititaan ja koetetaan arvailla, mitä itkijä teki väärin ansaitakseen moisen kohtelun (esim. 1582:23-26). Fyysiset esteet kuten hautaaminen syvään (3) tai suuret kivet mainitaan myös paluun esteenä:

\section{Taioitte panna paksut turpeet miun parkkulaisellen vai lie pannehet suuret kivet kirjoikapaloitusellen?}

$(1583: 29-30$.

Itkijä saattaa myös epäillä toimineensa itse väärin, koska vainaja jätti hänet eikä nyt vastaa puhutteluunkaan:

Vai olin tottelematon siulle miun tunittelijaiseni? Vai en käynyt siun käskyjäs miun käärijäiseni, niin byvästi kuin olisit tabtont miun tasoittajani?

$$
\text { (1861:6-8.) }
$$

Näissä pohdinnoissa yhdistyvät toisiinsa kulttuuriset Tuonela-käsitykset ja surevien psyykkiset tarpeet. Tekstin tasolla ne käyvät läpi suruprosessin vaiheita ja niihin liittyviä tunteita: tapahtuneen kieltämisen, katkeruuden vainajaa kohtaan ja mahdolliset syyllisyydenkin tunteet. Kun kulttuuri tarjoaa kanavan vainajille osoitetuille viesteille, myös kiintymyksen osoittaminen - kaiken sen sanominen, mikä jäi sanomatta - on tavallaan mahdollista jälkikäteen.

Suruprosessille tarpeellisen tunteiden käsittelyn ja katharsiksen näkökulmasta ei ole olennaista, uskooko riittiin osallistuva sanoman todella menevän perille. Rituaalissa tunteiden aitokin käsittely on etäistettyä ja itkijä tietää, etteivät 


\title{
KAARINA KOSKI
}

hänen pyyntönsä konkreettisesti johda mihinkään. Kuitenkin, kuten edellä on todettu, kommunikaatiota ei myöskään ole tuomittu täysin yksisuuntaiseksi vaan on ajateltu vainajien voivan kommentoida elävien yhteydenottoja ilmestymällä uniin (Nenola 2002, 738). Karjalassa univierailuja on nimenomaisesti pyydetty vainajilta; ilmestyminen uneen pyytämättä voidaan tulkita negatiiviseksi enteeksi (Järvinen 2004, 202). Inkeriläisissä itkuissakin vainajan pyytäminen uniin on yleistä. Purkaessaan pettymystään siitä, ettei vainaja enää nouse, yksi soikkolalaisitkijä - Johorkan nainen - onkin tehnyt edellä mainittuihin uskomuksiin nähden realistisen lisäyksen: hän pahoittelee sitä, ettei vainaja ole tullut hänen unïnsa.

\section{Taiettiin Kaivaa syvä hauta miun synnyteltysellen taiettiin panna kovaan maahan miun kuorimaisuein, kun ei voi näyttiä unes miulle uponnehelle itsellen [..]}

(1582:80-82.)

Kuolinitkujen sisältö muuntuu todellisten puitteiden mukaan myötäillen vainajan ja omaisten elämänhistoriaa, mutta ne eivät ole ensisijaisesti yksilöllisiä vaan muotoutuvat perinteisistä aineksista. Traditio antaa yksilölle mahdollisuuden ilmaista tuntojaan anonyymissa muodossa. Niin itku kuin lyyrinen laulukin ovat antaneet legitiimin kanavan ajatuksille, joiden esittäminen ei olisi ollut sanallisessa muodossa sosiaalisesti hyväksyttyä. Sepittäessään itsekin lisää säkeitä laulajalla ja itkijällä on ollut taustallaan tradition ja aiempien sukupolvien tuki. (Virtanen 1985, 127, 129; Apo 1989, 176-177.) Itku antoi mahdollisuuden puhutella vainajaa, mutta yhteisöllisessä rituaalissa itkun sanoin voitiin anoa myös apua kyläläisiltä (esim. 1879:9-13).

Soikkolalaisitkuille tyypilliset konkreettiset toiveet vainajan paluusta ovat perinteisiä, itkuvirren rakenteeseen kuuluvia motiiveja. Toisinaan ne sivuutetaan lyhyesti; toisinaan ne saavat suurenkin painon. Eri motiivien käyttö ja mahdollisuudet muunteluun määräytyvät paljolti itkun rituaalisen funktion perusteella. Yhteisölliseen riittiin kuuluvat itkut ovat huomattavasti tiukemmin säänneltyjä kuin myöhemmin omaisen haudalla itketyt tai tilapääitkut. (Honko 1963:113-114; ks. myös Nenola 2002, 738.)

Haudoilla käytäessä esitetyissä itkuissa esiintyvä yksilöllinen variaatio kertoo mielestäni eroa prosessoivien kollektiivisten motiivien aidosta merkityksellisyydestä. Itkijät muuntelevat itkujaan käsitelläkseen juuri itselleen kipeimpiä kysymyksiä. Muiden itkujen säkeistä poikkeavat yksilölliset pyynnöt ovat itkutekstejä lukiessa kaikkein pysähdyttävimpiä. Esimerkiksi aikuisen poikansa menettänyt äiti kutsuu tätä itkussaan tarttumaan työhön, aatraan tai viikatteeseen:

\author{
Etkö voi kohota käsin koroteltusein \\ atraan armas ak.kimaisuein \\ viikatteeseen hyvä bypiteltysein?
}

(1580: 6-8.) 


\section{SUHDE VAINAJAAN INKERILÄISISSÄ KUOLINITKUISSA}

Vainajaa, jolta on jäänyt pieniä lapsia, pyydetään usein ruokkimaan tai vaatettamaan lapsiaan tai silittämään heidän hiuksiaan (esim. 1577: 10-11, 1606: 10-14, 30-33, 1624: 8-10); kyseessä on kollektiivinen motiivi. Sen sijaan yksi nuoremmista sisaruksistaan huolehtimaan jäänyt tyttö pyytää äitivainajaansa myös imettämään haudalle tuomaansa lasta:

\section{Nouse maistuttele nännälläs maalle tuojasein kasta hot suuta sukimaiseltas.}

(1577: 8-9.)

Äiti on kuollut, mutta tyttö epäilemättä toivoo aidosti, että äiti eläisi ja voisi tyydyttää huutavan lapsen nälän ja kaipuun. Samassa tilanteessa orpo tyttö toivoo myös nuorempien sisarustensa kuolemaa. Tyttö myös kiittää äitiään siitä, että tämä oli jo ottanut yhden lapsista luokseen (1522:1-8), sekä Luojaa, jonka teoksi hän sen viime kädessä tulkitsee (1522:24-28). Tällaisista poikkeuksista huolimatta itkut yleensä piirtävät kuvaa kontaktin yksisuuntaisuudesta: vainaja ei tee sitä, mitä itkijä on häneltä pyytänyt. Itkijän sinnikkäätkin yritykset kuolleen omaisen nostamiseksi epäonnistuvat jokaisessa kokonaisena tallennetussa hautaitkussa, ja vainajan todetaan jäävän hautaan lopullisesti tai jo muuttuneen mullaksi, kuten seuraavissa esimerkeissä:

$$
\begin{gathered}
\text { Johan se on kylmänyt sun kieloseis kylmänkivoisen verralliseks, } \\
\text { joban se on kaubaellut bänen kaunehoinen kasvovartoseen, kaubaellut lahokannon } \\
\text { karvalliseks, } \\
\text { johan se on munttunut bänen mubiainen muotoseese mubiaisen mullan muotoiseks. } \\
\text { (1118:61-63.) }
\end{gathered}
$$

\section{A nyt jo ennää et noisekaa nosseteltuiseen \\ i etkä ennääkarke.kahu kailoikukeaiseen. \\ No olkoo sïs raubaas miun laaiteltuiseen \\ i mak.kaaha maas hooletas hooliteltuiseen.}

$$
(1635: 25-28 .)(4)
$$

Itkut siis sisältävät retorisen käänteen: itkijä ei ensin ole ymmärtävinään tosiasioita. Karjalassa sama tapahtuu itkijän esittämin hämmästelevin kysymyksin: "Miksi panette hänet arkkuun?” ja kielloin: "Älkää tehkö sitä!’ Itkun edetessä epärealistiset toiveet raukeavat riitin lopullista tarkoitusta, luopumisen hyväksymistä myötäileviin säkeisiin. (Honko 1963, 109-110, 114.) Tällainen retoriikka on suremiseen pakottava tyylikeino. Itkuissa esitetyt jälleennäkemisen toiveet pyrkivät vaimentamaan surua ja lohduttomuutta, mutta juuri niiden mahdottomuus kirvoittaa itkijältä ja kuulijoilta vain lisää kyyneliä (Konkka 1985, 68). 


\section{LOPUKSI}

Edellä olen selvitellyt joitakin syitä siihen, miksi inkeriläisten itkujen ilmentämä vainajasuhde on sellainen kuin on. Kulttuuris-uskonnollinen selitys itkujen vainajasuhteen tuttavallisuuteen, etenkin verrattuna vainajien pelkoa ilmentäviin uskomuksiin, on rituaalisuus. Rituaali varmistaa asianmukaisen siirtymisen tuonpuoleiseen, jolloin vainaja ei ole katkera tai vaarallinen. Lisäksi rituaaleihin kuuluu varautuminen, ja kiintymystä ilmaiseva yhteydenpito itkuin myös varmistaa edesmenneiden myötämielisyyden eläviä kohtaan. Äänelläitkemisen instituutio on rohkaissut pitämään yllä yhteyksiä tuonpuoleiseen, mitä vuodentulon turvaamiseen tähtäävä uskonto on edellyttänytkin.

Luterilaisessa Suomessa vainajasuhteet rakennettiin aivan toisenlaiselta pohjalta: kirkko edellytti suhteiden katkaisemista kuolemassa (esim. Sarmela 1994, 59). Ensinnäkin vainajakultti nakersi kirkon arvovaltaa ja toiseksi sen päämäärät olivat aineellisia, toisin kuin kristinuskon. Kristillisen Suomen henkisessä ilmapiirissä muotoutuneet uskomustarinat heijastelevat ideologiaa, joka tyrmää vainajakontaktien kannattavuuden tai houkuttelevuuden. Kuitenkin Inkerissä kuolinitkuja esittivät myös luterilaiset, ja samalla väestö tunsi vainajakontaktien vaarallisuutta propagoivia uskomustarinoita. Tällainen ristiriita on kansanuskolle tyypillinen ilmiö. Erilaiset mielikuvat, ideologiat ja toimintastrategiat otetaan käyttöön kulloisenkin tarpeen mukaan.

Itkujen merkitys on jo 1800-luvulla ollut yhä painokkaammin emotionaalinen. Tuskan tuulluttamisen välineinä itkut hakevat yhteyttä kaivattuihin sellaisina kuin heitä kaivataan eli oikeina ihmisinä: henkisinä tukina, neuvojina, leivän hankkijoina, pellon auraajina - ja persoonaltaan samanlaisina kuin eläessään. Itkijöillä on mahdollisuus purkaa ahdistustaan myös ilmaisemalla suorasukaisesti, mitä he olisivat vainajalta halunneet - vaikkakin pohjimmiltaan tietäen, etteivät sellaiset toiveet ole enää toteutettavissa. Toisin sanoen läheinen suhde on ollut tarkoituksenmukainen sekä kulttuuris-uskonnollisista että emotionaalisista syistä.

Psykoanalyyttinen näkökulma surun ritualisointiin auttaa ymmärtämään joitakin inkeriläisten itkujen teemoja ja motiiveja. Psykoanalyytikoiden edellyttämä täydellinen irrottautuminen vainajan muistosta paljastuu kuitenkin kulttuurisidonnaiseksi tavoitteeksi, johon ei pyritä elävää äänelläitkemisen tai vainajien muistelun (pominoinnin) traditiota ylläpitävissä kulttuureissa.

\section{VIITTEET}

1. Itkujen numerointi perustuu järjestelmään, jossa nelinumeroisen sarjan ensimmäinen numero on lajikoodi: 1 kuolinitku, 2 hääitku, 3 rekryytti-itku, 4 tilapääitku. Toinen numero on aluekoodi: 1 Pohjois-Inkeri, 2 Äyrämöiset, 3 Hevaa, 4-5-6 Soikkola, 7 Vatjalaiset ja 8-9 Laukaa (Viron Inkeri). Kaksi viimeistä numeroa ilmaisevat itkujen ikäjärjestyksen. (Nenola 2002, 46, 877; Nenola-Kallio 1982, 275.) 
Kokoelmaan kuuluu 674 itkuvirsitekstiä. Toisintoluettelossa on lisäksi 20 sellaista tekstiä tai sävelmää, joita ei ole julkaistu uudelleen; muutamaa lukuun ottamatta kokoelma sisältää kuitenkin kaiken, mitä Inkeristä on tallennettu. (Nenola 2002, 37.)

2. Vainajalle osoitettu kehotus nousta työhön on legitiimi itkuvirsissä, mutta rangaistava uskomustarinoissa. Tällaisia tarinoita on tallennettu luterilaisesta Suomesta huomattavasti enemmän kuin Inkeristä. Määrät eivät kuitenkaan ole vertailukelpoisia, koska Inkeri ei valtiopoliittisista syistä enää kuulunut keruun piiriin 1930-luvulla, jolloin suuri osa uskomustarinoista on tallennettu. Inkeristä (perinnealue s) on tallennettu myös kotonakulkijoita kuvaavia tarinoita, mutta etenkin jos vainaja on tuttu, tällä saattaa olla myös positiivinen rooli (esim. tarinatyyppi C 497, Jauhiainen 1999, 99).

3. Tähän teemaan viitataan myös itkuissa, joita esitetään vietäessä arkkua hautaan. Soikkolalainen Akulina Kirillova itkee äidin kuoltua: älkää haudatko syvään. Jos minulle tulee kova ikävä, kaivan hänet ylös, asetan ristin nojalle ja itken hänelle suruni. Tulen sinua nostamaan, siirrän hiekat ja turpeet sivuun. Jos olet jo painunut maahan, nostan sinut köysien avulla. Mutta jos olet jo niin maan sitoma, ettet nouse köysilläkään, odotan kevättä, että nousisit nuoren heinän mukana ja lentäisit lehden sisässä luoksemme (1605, 1621, 1622).

4. Kuoleman lopullisuuden teema esiintyy myös hääitkuissa, joissa puhutellaan vainajia, mutta kuolinitkuihin verrattuna tiiviimpänä pakettina:

\author{
Kaivaisin kääpän kässiil, sortuttaisin somerot sormïl \\ nostaisin mie sinun nuorïni nojal \\ panisin mie siun patsaisini varoil, \\ vet sie oot jo munttunut mullaksi miun muurentuojani \\ $i$ sie oot jo lietyt liivaksi miun liekuttajani \\ sie oot jo maattut maaksi miun maalen tuojani!
}

(2897:9-14.)

\title{
KiRJallisuUs
}

ALEXIOU, MARGARET 1974: The Ritual Lament in Greek Tradition. Cambridge: Cambridge University Press.

APO, SATU 1989: Nainen ja kuolema. Karjalaiset itkuvirret; Valitus ja viha. Lyyrinen laulurunous. - Maria-Liisa Nevala (toim.), "Sain roolin johon en mahdu". Suomalaisen naiskirjallisuuden linjoja. Helsinki: Otava.

BERGER, PETER \& LUCKMANN, THOMAS 1994: Todellisunden sosiaalinen rakentuminen. Helsinki: Gaudeamus.

BLOCH, MAURICE \& PARRY, JONATHAN 1982: Introduction: Death and the Regeneration of Life. - Maurice Bloch \& Jonathan Parry (eds.), Death and the Regeneration of Life. Cambridge: Cambridge University Press. 
CAVENDISH, RICHARD 1975: The Powers of Evil in Western Religion, Magic and Folk Belief. London: Routledge \& Kegan Paul.

DURKHEIM, ÉMILE 1980: Uskontoelämän alkeismuodot. Australialainen toteemijärjestelmä. Helsinki: Tammi. [1912]

FREUD, SIGMUND 1989: Toteemi ja tabu. Eräitäybtäläisyylesiä villien ja neuroottisten sielunelämässä. Helsinki: Love Kirjat.

HAAVIO, MARTTI 1930: Savvaitovin, Lytkinin ja Wichmannin keräämät syrjääniläist hääitkut. - Suomi 5(10): 90-136.

- 1950: Sielulintu. Eräiden motiivien selvittelyä. - Kalevalaseuran Vuosikirja 30. Porvoo: WSOY.

HONKO, LAURI 1963: Itkuvirsirunous. - Matti Kuusi (toim.), Suomen kirjallisuus I. Kirjoittamaton kirjallisuus. Helsinki: Otava.

- 1974: Balto-Finnic Lament Poetry. - Pentti Leino (ed.), Finnish Folkloristics I. Studia Fennica 17. Helsinki: Finnish Literature Society.

- 1978: The Ingrian Lamenter as Psychopomp. - Temenos 14: 79-96.

INKERIN ITKUVIRRET - INGRIAN LAMENTS. Ks. Nenola 2002.

JAUHIAINEN, MARJATTA 1999: Suomalaiset uskomustarinat. Tyypitja motiivit. Suomalaisen Kirjallisuuden Seuran Toimituksia 731. Helsinki: Suomalaisen Kirjallisuuden Seura.

JÄRVINEN, IRMA-RIITTA 2004: Karjalan pybät kertomukset. Tutkimus livvinkielisen alueen legendaperinteestä ja kansanuskon muntoksista. Suomalaisen Kirjallisuuden Seuran Toimituksia 962. Helsinki: Suomalaisen Kirjallisuuden Seura.

KLEINPAUL, RUDOLF 1898: Die Lebendigen und die Toten in Volkglauben, Religion und Sage. Leipzig: G.J. Göschen'sche Verlagshandlung.

KONKKA, UNELMA 1985: Ikuinen ikävä. Karjalaiset riitti-itkut. Suomalaisen Kirjallisuuden Seuran Toimituksia 428. Helsinki: Suomalaisen Kirjallisuuden Seura.

LAZARUS, RICHARD S. 1999: Stress and Emotion. A New Synthesis. London: Free Association Books.

MALINOWSKI, BRONISLAW 1960: Magia, tiede ja uskonto sekä muita esseitä. PorVOO: WSOY.

METCALF, PETER \& HUNTINGTON, RICHARD 1991: Celebrations of Death. The Anthropology of Mortuary Ritual. Second Edition. Cambridge: Cambridge University Press.

NENOLA(-KALLIO), AILI 1973: Inkerin itkuvirsialuejako. - Sananjalka 15: 93-120.

- 1982: Studies in Ingrian Laments. FF Communications 234. Helsinki: Suomalainen tiedeakatemia.

- 1985: Kuolema, yksilö ja yhteisö. Kuolemanrituaalien alustavaa tarkastelua. - Junnonaho, Martti (toim.), Folkloristiik.kaa ja uskontotiedettä. Etiäinen 1. Turku: Turun yliopisto, kulttuurien tutkimuksen laitos.

- 1986: Miessydäminen nainen. Naisnäkökulmia kulttuurïn. Tietolipas 102. Helsinki: Suomalaisen Kirjallisuuden Seura.

— 1991: Det finns många ord för sorg men få för smärta. - Tradisjon 21: 15-21.

- 2002: Inkerin itkuvirret - Ingrian Laments. Suomalaisen Kirjallisuuden Seuran Toimituksia 735. Helsinki: Suomalaisen Kirjallisuuden Seura. 
SUHDE VAINAJAAN INKERILÄISISSÄ KUOLINITKUISSA

POLLOCK, GEORGE H. 1972: On Mourning and Anniversaries: The Relationship of Culturally Constituted Defensive Systems to Intra-psychic Adaptive Processes. - The Israel Annals of Psychiatry and Related Disciplines. 10(1): 9-40.

- 1974: Mourning and Adaptation. - Robert A. LeVine (ed.), Culture and Personality. Contemporary Readings. Chicago: Aldine Publishing Company.

PURHONEN, PAULA 1998: Kristinuskon saapumisesta Suomeen. Suomen muinaismuistoyhdistyksen aikakauskirja 106. Helsinki: Suomen Muinaismuistoyhdistys. ROSENBLAT'T, PAUL C. \& WALSH, R. PATRICIA \& JACKSON, DOUGLAS A. 1976: Grief and Mourning in Cross-Cultural Perspective. New Haven: HRAF Press. SALMINEN, VÄINÖ 1916: Inkerin kansan häärunoelma muinaisine kosimis- ja bäämenoineen. Suomalaisen Kirjallisuuden Seuran Toimituksia 155. Helsinki: Suomalaisen Kirjallisuuden Seura.

- 1945: Etelä-Karjalan runonlaulajat ja tietäjät. Eripainos teoksesta Etelä-Karjalan runot 4 (Suomen kansan vanhat runot XIII, 4). Helsinki: Suomalaisen Kirjallisuuden Seura.

SARMELA, MATTI 1994: Suomen Perinneatlas. Suomen kansankulttuurin kartasto 2. Suomalaisen Kirjallisuuden Seuran Toimituksia 587. Helsinki: Suomalaisen Kirjallisuuden Seura.

SCHEFF, THOMAS J. 1977: The Distancing of Emotion in Ritual. - Current Anthropology 18(3): 483-505.

STARK, LAURA \& JÄRVINEN, IRMA-RIITTA \& TIMONEN, SENNI \& UT-

RIAINEN, TERHI 1996: Constructing the Moral Community: Women's Use of Dream Narratives in a Russian-Orthodox Karelian Village. - Robert B. Pynsent (ed.), The Literature of Nationalism. Essays on East European Identity. London: Macmillan Press Ltd.

TIMONEN, SENNI 2004: Minä, tila, tunne. Näkökulmia kalevalamittaiseen kansanlyrïkkaan. Suomalaisen Kirjallisuuden Seuran Toimituksia 963. Helsinki: Suomalaisen Kirjallisuuden Seura.

UTRIAINEN, TERHI 1998: Feminine and Masculine in the Study of Balto-Finnic Laments. - Apo, Satu \& Nenola, Aili \& Stark-Arola, Laura (eds.), Gender and Folklore. Perspectives on Finnish and Karelian Culture. Studia Fennica Folkloristica 4. Helsinki: Finnish Literature Society.

— 1999: Läsnä, riisuttu, pubdas. Uskontoantropologinen tutkimus naisista kuolevan vierellä. Suomalaisen Kirjallisuuden Seuran Toimituksia 751. Helsinki: Suomalaisen Kirjallisuuden Seura.

TÖRNEROOS, ANTTI \& TALLQVIST, THEODOR 1860: Kertomus Runonkeruu-matkasta Inkerissä, kesällä 1859. - Suomi 1860: 125-157.

VIRTANEN, LEEA 1985: Naiset kalevalaisen lyriikan esittäjinä. - Kotiseutu 3: 124-130.

WESTERMARCK, EDVARD 1908: The Origin and Development of the Moral Ideas.

Vol II. London: Macmillan and co.

\section{Kaarina Koski (FM) valmistelee väitöskirjaa folkloristiikan oppiaineeseen.}

